\title{
STUDI DANA DEKONSENTRASI DAN TUGAS PEMBANTUAN DI LINGKUNGAN KEMENTERIAN DALAM NEGERI*
}

\section{STUDY DECONCENTRATION FUND AND ASSISTANCE TASKS IN THE MINISTRY OF HOME AFFAIRS}

\author{
Hasoloan Nadeak \\ Badan Penelitian dan Pengembangan Kementerian Dalam Negeri \\ Jalan Kramat Raya No.132 Jakarta Pusat \\ Tlp. +6221 73457064 Hp. +62 82163906021 \\ Diterima: 3 Januari 2012, Direvisi: 8 Februari 2012, Disetujui: 27 Februari 2012
}

\begin{abstract}
Abstrak
Permasalahan studi ini adalah bagaimana perencanaan dan penganggaran, pelaksanaan serta pelaporan, dan strategi untuk perbaikan pelaksanaan kegiatan Dekonsentrasi dan Tugas Pembantuan di lingkungan Kementerian Dalam Negeri (Kemendagri). Pendekatan terhadap permasalahan tersebut adalah menggunakan pendekatan metode gabungan antara deskriptif kualitatif dan kuantitatif dengan teknik analisis SWOT. Berdasarkan pendekatan dimaksud, maka diketahui bahwa dalam pelimpahan dan penugasan urusan Kemendagri melalui Dekonsentrasi dan Tugas Pembantuan belum optimal, dalam menyusun perencanaan dan penganggaran kegiatan Dekonsentrasi dan Tugas Pembantuan masih ada yang menggunakan mekanisme di luar musrenbangnas melainkan melalui usulan non formal lewat surat-menyurat/proposal, penyerahan (daftar isian penggunaan anggaran) DIPA kepada satuan unit perangkat daerah (SKPD) sering terlambat yang berakibat pada pencairan dana Dekonsentrasi dan Tugas Pembantuan terlambat, penetapan pejabat pelaksana Dekonsentrasi dan Tugas Pembantuan pada SKPD sering terlambat. Kemudian dengan perhitungan terhadap kondisi pelaksanaan dan pelaporan dengan menggunakan Skala Likert, diperoleh hasil bahwa yang mendapatkan nilai yang kecil yaitu variabel laporan realisasi anggaran dan penatausahaan barang.

Kata kunci: evaluasi, dekonsentrasi, tugas pembantuan, analisis SWOT
\end{abstract}

\begin{abstract}
Problems of this study is how the planning and budgeting, implementation and reporting, and strategies to improve implementation of Deconcentration and Assistance Duty in the Ministry Home Affairs. Approach to these problems is to use a combined method approach of qualitative and quantitative descriptive techniques SWOT analysis. Based on the intended approach, it is known that the transfer and assignment of the affairs of the Ministry of Home Affairs through the Deconcentration and Assistance Duty have not been optimal, in planning and budgeting activities Deconcentration and Assistance Duty still exist that use a mechanism outside Musrenbangnas but through non formal proposal through correspondence / proposal, the submission (budget use of checklists) DIPA to the local units (SKPD) is often delayed, resulting in the withdrawal of funds Deconcentration and Assistance Duty too late, the determination of executive officers on Deconcentration and Assistance Duty SKPD often too late. Then the calculation of the condition of the implementation and reporting by using a Likert Scale, obtained results that are getting little value that the variable budget reports and administration of goods.

Keywords: evaluation, deconcentration, assistance duty, SWOT analysis
\end{abstract}

\section{PENDAHULUAN}

Penyelenggaraan pemerintahan daerah merupakan salah satu amanat Undang-Undang Dasar Negara Kesatuan Republik Indonesia (UUD NKRI) Tahun 1945. Pasal 18, Pasal 18A, dan Pasal 18B UUD 1945 menyebutkan bahwa pemerintahan daerah mengatur dan mengurus sendiri urusan pemerintahan menurut asas otonomi dan tugas pembantuan. Pelaksanaan otonomi ini diarahkan untuk mempercepat terwujudnya kesejahteraan masyarakat melalui peningkatan pelayanan, pemberdayaan, dan peran serta masyarakat, serta peningkatan daya saing daerah dengan memperhatikan prinsip demokrasi, pemerataan, keadilan, keistimewaan dan kekhususan suatu daerah dalam sistem Negara Kesatuan Republik Indonesia (NKRI).

Amanat UUD 1945 dimaksud, secara eksplisit menegaskan tiga (3) hal penting, yaitu: pertama, terkait dengan hubungan kewenangan; kedua, hubungan keuangan; dan ketiga, menyangkut penyelenggaraan pemerintahan daerah, yang pelaksanaannya diatur lebih lanjut dengan undangundang tersendiri. Landasan hukum penyelenggaraan pemerintahan daerah saat ini adalah UU 
No.32 Tahun 2004 tentang Pemerintahan Daerah dan Undang-Undang Nomor 33 tahun 2004 Tentang Perimbangan Keuangan antara Pemerintah Pusat dan Pemerintahan Daerah, beserta peraturan pelaksanaan lainnya.

Undang-Undang Nomor 32 Tahun 2004 khususnya Pasal 10 ayat (4) menyebutkan "Dalam menyelenggarakan urusan pemerintahan sebagaimana dimaksud pada ayat (3) pemerintah menyelenggarakan sendiri atau dapat melimpahkan sebagian urusan pemerintahan kepada perangkat pemerintah atau wakil pemerintah di daerah atau dapat menugaskan kepada pemerintahan daerah dan/atau pemerintahan desa". Selanjutnya ayat 5 menyebutkan "Dalam urusan pemerintahan yang menjadi kewenangan pemerintah di luar urusan pemerintahan sebagaimana dimaksud pada ayat (3), pemerintah dapat : a) menyelenggarakan sendiri sebagian urusan pemerintahan, b) Melimpahkan sebagian urusan pemerintahan kepada Gubernur selaku wakil pemerintah, atau c) Menugaskan sebagian urusan kepada pemerintahan daerah dan/atau pemerintahan desa berdasarkan asas tugas pembantuan". Pasal 12 ayat (2) UU No. 32 Tahun 2004 juga menyebutkan "Urusan pemerintahan yang dilimpahkan kepada Gubernur disertai dengan pendanaan sesuai dengan urusan yang didekonsentrasikan."

Dalam rangka memberikan pedoman dalam pelaksanaan dekonsentrasi dan tugas pembantuan, pemerintah telah menetapkan Peraturan Pemerintah (PP) Nomor 7 Tahun 2008 tentang Dekonsentrasi dan Tugas Pembantuan yang secara normatif mengatur antara lain: a) Dana dekonsentrasi dan tugas pembantuan hanya digunakan untuk mendanai program/kegiatan yang menjadi urusan pemerintah pusat. Oleh karena itu, kementerian/lembaga wajib memprakasai penyusunan program/kegiatan dekonsentrasi dan tugas pembantuan sesuai dengan Renstra KL, Rencana Kerja KL dan ketentuan pembagian urusan, b) Rencana lokasi dan anggaran untuk program dan kegiatan yang akan didekonsentrasikan/ ditugasbantuankan disusun dengan memperhatikan kemampuan keuangan negara, keseimbangan pendanaan di daerah dan kebutuhan pembangunan daerah, c) Pendanaan tugas pembantuan ditujukan untuk kegiatan yang bersifat fisik, yaitu kegiatan yang output-nya berimplikasi terhadap penambahan nilai aset pemerintah, sementara output belanja bantuan sosial atau belanja barang tidak berimplikasi terhadap penambahan nilai aset pemerintah tersebut, d) Semua barang yang dibeli atau diperoleh dari pelaksanaan dana dekonsentrasi dan tugas pembantuan merupakan barang milik negara (BMN). Barang tersebut dapat dihibahkan kepada daerah dan apabila sudah dihibahkan, maka daerah wajib mengelola dan menatausahakannya sebagai barang milik daerah.

PP No. 7 Tahun 2008 tentang Dekonsentrasi dan Tugas Pembantuan ditindaklanjuti dengan
Peraturan Menteri Keuangan (PMK) Nomor 156 Tahun 2008 yang disempurnakan dengan PMK No. 248 Tahun 2010 tentang Pedoman Pengelolaan Dana Dekonsentrasi dan Dana Tugas Pembantuan yang mengatur tentang hal-hal terkait dengan pola dan mekanisme pendanaan dekonsentrasi dan tugas pembantuan yang wajib diikuti oleh seluruh penyelenggaraan kegiatan dekonsentrasi dan tugas pembantuan. Pengaturan pendanaan tersebut bertujuan agar pengelolaan dana dekonsentrasi dan dana tugas pembantuan dilakukan sesuai dengan prinsip-prinsip pengelolaan keuangan negara, sebagaimana diamanatkan dalam Pasal 3 ayat (1) UU Nomor 17 Tahun 2003 tentang Keuangan Negara yaitu, "Keuangan Negara wajib dikelola secara tertib, taat pada peraturan perundang-undangan, efisien, ekonomis, efektif, transparan dan bertanggungjawab dengan memperhatikan rasa keadilan dan kepatutan".

Dalam penyelenggaraan dekonsentrasi dan tugas pembantuan lingkup Kemendagri, sesuai dengan data yang ada $\pm 60 \%-80 \%$ dari total anggaran Kementerian dalam Negeri ditransfer ke daerah dalam kaitan pelaksanaan urusan Kementerian Dalam Negeri di daerah. Salah satu dampak yang ditimbulkan sekaligus masalah adalah dapat menghambat pencapaian opini Wajar Tanpa Pengecualian (WTP) atas kinerja Kemendagri, karena masih lemahnya pengelolaan keuangan dan barang milik negara (aset) baik Pemerintah Daerah (SKPD) selaku pelaksana kegiatan dekonsentrasi dan tugas pembantuan maupun Pemerintah Pusat (Unit Eselon 1) selaku pengelola dekonsentrasi dan tugas pembantuan.

Disamping itu PP No. 7 Tahun 2008 tentang Dekonsentrasi dan Tugas Pembantuan, yang tidak mengatur/ mewajibkan kementerian/lembaga pengelola dekonsentrasi dan tugas pembantuan untuk melakukan penata-usahaan barang/aset hasil kegiatan dekonsentrasi dan tugas pembantuan Kementerian /lembaga yang bersangkutan, sebelum status barang/aset dimaksud dihibahkan kepada pemerintah daerah. Dalam kaitan itu semua, maka evaluasi dana Dekonsentrasi dan Tugas Pembantuan di lingkungan Kemendagri menjadi relevan dan up-to-date untuk dilakukan kajiannya.

Untuk melihat realitas permasalahan studi ini diidentifikasi kedalam dua hal yaitu: 1) implementasi kebijaka dana dekonsentrasi tugas pembantuan belum sesuai dengan peraturan perundang-undangan, 2) kegiatan dekonsentrasi dan tugas pembantuan, terkait dengan perencanaan, penganggaran, pelaksanaan serta pelaporan masih menemui permasalahan dan hambatan. Oleh karena itu, studi ini secara khusus fokus pada masalah yang terkait dengan perencanaan, penganggaran, pelaksanaan serta pelaporan kegiatan dekonsentrasi dan tugas pembantuan di lingkungan Kemendagri.

Dengan demikian, maka permasalahannya dapat dirumuskan yaitu: 1) bagaimanakah 
perencanaan, penganggaran, pelaksanaan serta pelaporan dalam pelaksanaan kegiatan dekonsentrasi dan tugas pembantuan di lingkungan Kemendagri? 2) bagaimanakah strategi untuk perbaikan pelaksanaan kegiatan dekonsentrasi dan tugas pembantuan di lingkungan Kemendagri?

Terkait dengan rumusan permasalahan dimaksud, maka ruang lingkup studi ini adalah: a) menginventarisir permasalahan dan hambatan, serta solusi untuk perbaikan terkait perencanaan dan penganggaran, pelaksanaan dan pelaporan pelaksanaan kegiatan Dekonsentrasi dan Tugas Pembantuan di lingkungan Kemendagri; b) Menyusun strategi untuk perbaikan terkait perencanaan dan penganggaran, pelaksana-an dan pelaporan pelaksanaan kegiatan Dekonsentrasi dan Tugas Pembantuan di lingkungan Kemendagri.

\section{METODE PENELITIAN}

Metode yang digunakan dalam studi ini adalah menggunakan pendekatan metode gabungan antara deskriptif kualitatif dan kuantitatif. Dengan menggunakan metode ini, studi ini hendak melihat kondisi yang ada, yang bekaitan dengan perencanaan dan penganggaran, pelaksanaan serta pelaporan pelaksanaan Dekonsentrasi dan Tugas Pembantuan yang dilaksanakan oleh pemerintah daerah/SKPD berdasarkan peraturan perundang-undangan yang berlaku saat ini.

Studi dilaksanakan dengan cara sample research dengan lokasi kajian dipilih secara purposive sampling yakni berdasarkan ciri-ciri kinerja keuangan di 4 (empat) provinsi, yaitu Banten, Jawa Tengah, DI Yogyakarta, dan Sulawesi Utara. Adapun yang menjadi subyek kajian ini dan sekaligus informan adalah penerima dana Dekonsentrasi dan Tugas Pembantuan yaitu Satuan Kerja penerima dana dekonsentrasi dan tugas pembantuan seperti Bappeda, Kesbang dan Linmas serta Kepala Biro pada Setda Provinsi Daerah sampel.

Penentuan informan dalam studi ini didasarkan pada metode purposive sampling yaitu penunjukan sampel informan didasarkan pada ciriciri tertentu yaitu sebagai penerima, pelaksana dan

Tabel 1. Variabel, Sub Variabel, Indikator dan Sumber Data

\begin{tabular}{|c|c|c|c|}
\hline Variabel & Sub Variabel & Indikator & $\begin{array}{c}\text { Sumber } \\
\text { Data }\end{array}$ \\
\hline \multirow[t]{3}{*}{$\begin{array}{l}\text { Perencanaan dan } \\
\text { Penganggaran }\end{array}$} & Koordinasi & $\begin{array}{ll}\text { 1. } & \text { hirarki manajerial } \\
\text { 2. } & \text { aturan dan prosedur } \\
\text { 3. } & \text { rencana dan pencapaian }\end{array}$ & $\begin{array}{l}\text { Dokumen } \\
\text { dan } \\
\text { Informan }\end{array}$ \\
\hline & Pelimpahan & 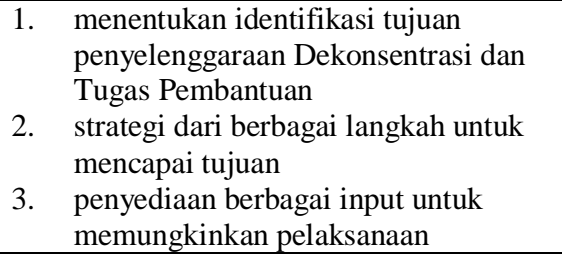 & $\begin{array}{l}\text { Dokumen } \\
\text { dan } \\
\text { Informan }\end{array}$ \\
\hline & $\begin{array}{l}\text { Tata cara } \\
\text { pelimpahan }\end{array}$ & $\begin{array}{l}\text { 1. mengurus dan mengatur semua urusan } \\
\text { 2. menangani urusan pemerintah } \\
\text { berdasarkan tugas dan wewenang } \\
\text { 3. membuat kebiijakan sesuai dengan } \\
\text { kewenangan } \\
\text { 4. menangani urusan pemerintah yang } \\
\text { berpotensi dan memiliki ciri khas } \\
\text { 5. meningkatkan kesejahteraan rakyat }\end{array}$ & $\begin{array}{l}\text { Dokumen } \\
\text { dan } \\
\text { Informan }\end{array}$ \\
\hline \multirow[t]{2}{*}{$\begin{array}{l}\text { Pelaksanaan dan } \\
\text { Pelaporan }\end{array}$} & $\begin{array}{l}\text { Aspek } \\
\text { manajerial }\end{array}$ & $\begin{array}{l}\text { 1. Perkembangan realisasi penyerapan } \\
\text { dana } \\
\text { 2. Pencapaian target } \\
\text { 3. Kendala yang dihadapi } \\
\text { 4. Saran dan tindak lanjut }\end{array}$ & $\begin{array}{l}\text { Dokumen } \\
\text { dan } \\
\text { informan }\end{array}$ \\
\hline & $\begin{array}{l}\text { Aspek } \\
\text { akuntabilitas }\end{array}$ & $\begin{array}{ll}\text { 1. Laporan Realisasi Anggaran (LRA) } \\
\text { 2. Neraca } \\
\text { 3. Catatan Atas Laporan Keuangan } \\
\text { (CALK) } \\
\text { 4. Laporan Barang }\end{array}$ & $\begin{array}{l}\text { Dokumen } \\
\text { dan } \\
\text { informan }\end{array}$ \\
\hline \multirow[t]{2}{*}{$\begin{array}{l}\text { Monitoring dan } \\
\text { Evaluasi }\end{array}$} & Monitoring & $\begin{array}{ll}\text { 1. } & \text { Pelaporan } \\
\text { 2. } & \text { Pengendalian internal } \\
\text { 3. } & \text { Laporan keuangan } \\
\end{array}$ & $\begin{array}{l}\text { Dokumen } \\
\text { dan } \\
\text { informan }\end{array}$ \\
\hline & Evaluasi & $\begin{array}{l}\text { 1. Pelaksanaan } \\
\text { 2. Pasca pelaksanaan }\end{array}$ & $\begin{array}{l}\text { Dokumen } \\
\text { dan } \\
\text { informan }\end{array}$ \\
\hline
\end{tabular}

Sumber: Data diolah, 2011 
penanggung jawab kewenangan yang di Dekonsentrasikan dan Tugas Pembantuan.

Data yang dibutuhkan berupa data sekunder dan data primer. Data sekunder diambil dari instansi/satuan kerja informan. Data primer berupa kuesioner dan wawancara, informan kunci wawancara yaitu dengan Biro Perencanaan dan Pusat Administrasi Keuangan Pengelolaan Aset (AKPA) Kemendagri, SKPD (Bappeda, Biro Pemerintahan, Dinas Pengelolaan Keuangan dan Aset, Dinas Pemberdayaan Masyarakat Desa, Dinas Kesbang dan Linmas) di lokasi daerah sampel.

Variabel atau aspek yang diperhitungkan meliputi aspek seperti yang disusun dalam instrumen penelitian, sebagaimana disajikan pada Tabel 1 .

Analisis deskriptif menjadi pokok dalam melaksanakan kajian ini, di mana dengan analisis ini, yang digabungkan dengan analisis SWOT (strengths, weaknesses, opportunities and threats), dimungkinkan akan diperoleh kejelasan strategi kebijakan untuk penanganan permasalahan yang mungkin muncul dalam aspek, variabel bahkan indikator untuk wilayah kajian.

Analisis deskriptif kuantitatif dilakukan dengan menggunakan skala Likert untk mencari ratarata jawaban responden. Skala Likert digunakan untuk mengetahui persepsi atau pendapat responden, dimana penilaian menggunakan skala Likert yang mengkuantifikasikan jawaban ke dalam 5 (lima) kelompok, yaitu: 1 = sangat tidak baik, 2 = kurang baik, 3 = cukup baik, 4 = baik dan $5=$ sangat baik.

Skala Likert tersebut digunakan untuk menghitung rata-rata nilai jawaban responden, dari rata-rata tersebut kemudian jawaban responden dikelompokkan ke dalam 5 kategori. Langkahlangkah untuk menentukan kategori tersebut adalah sebagai berikut, rumus mencari interval (i) secara umum sebagai berikut :

$\mathrm{i}=\frac{\mathrm{H}-\mathrm{L}}{\mathrm{K}}$

Dimana $\mathbf{i}$ adalah besar kelas interval, $\mathbf{H}$ adalah nilai observasi yang paling tinggi, $\mathbf{L}$ adalah nilai observasi yang paling rendah, dan $\mathbf{K}$ adalah banyaknya kelas.

Maka didapatkan rentang nilai dan kategori untuk penilaian dengan menggunakan skala Likert:

Tabel 2. Rentang Nilai dan Kategori Skala Likert

\begin{tabular}{cc}
\hline Interval Penilaian & Kriteria \\
\hline $1-1.8$ & Sangat Tidak Baik \\
\hline $1.81-2.6$ & Kurang Baik \\
\hline $2.61-3.4$ & Cukup Baik \\
\hline $3.41-4.2$ & Baik \\
\hline $4.21-5$ & Sangat Baik \\
\hline
\end{tabular}

Sumber: Hasil Penelitian Puslitbang Keuda.

Data Diolah, 2011.
Sedangkan untuk analisis SWOT dilakukan melalui tiga tahap, yaitu:

1. Melakukan perhitungan skor (a) dan bobot (b) point faktor serta jumlah total perkalian skor dan bobot ( $=$ a $\mathrm{x}$ b) pada setiap faktor S-W-O$\mathrm{T}$; Menghitung skor (a) masing-masing point faktor dilakukan secara saling bebas (penilaian terhadap sebuah point faktor tidak boleh dipengaruhi atau mempengaruhi penilaian terhadap point faktor lainnya. Pilihan rentang besaran skor sangat menentukan akurasi penilaian yang digunakan adalah dari 1 sampai 4, dengan asumsi nilai 1 berarti skor yang paling rendah dan 4 berarti skor yang paling tinggi. Perhitungan bobot (b) masing-masing point faktor dilaksanakan secara saling ketergantungan. Artinya, penilaian terhadap satu point faktor adalah dengan membandingkan tingkat kepentingannya dengan point faktor lainnya. Sehingga formulasi perhitungannya adalah nilai yang telah didapat (rentang nilainya sama dengan banyaknya point faktor) dibagi dengan banyaknya jumlah point faktor).

2. Melakukan pengurangan antara jumlah total faktor $\mathrm{S}$ dengan $\mathrm{W}$ (d) dan faktor $\mathrm{O}$ dengan $\mathrm{T}$ (e); Perolehan angka $(\mathrm{d}=\mathrm{x})$ selanjutnya menjadi nilai atau titik pada sumbu $\mathrm{X}$, sementara perolehan angka $(\mathrm{e}=\mathrm{y})$ selanjutnya menjadi nilai atau titik pada sumbu $\mathrm{Y}$;

3. Mencari posisi organisasi yang ditunjukkan oleh titik $(\mathrm{x}, \mathrm{y})$ pada kuadran.

\section{Kuadran I (positif, positif)}

Posisi ini menandakan sebuah organisasi yang kuat dan berpeluang, Rekomendasi strategi yang diberikan adalah Progresif, artinya organisasi dalam kondisi prima dan mantap sehingga sangat dimungkinkan untuk terus melakukan ekspansi, memperbesar pertumbuhan dan meraih kemajuan secara maksimal.

\section{Kuadran II (positif, negatif)}

Posisi ini menandakan sebuah organisasi yang kuat namun menghadapi tantangan yang besar. Rekomendasi strategi yang diberikan adalah Diversifikasi Strategi, artinya organisasi dalam kondisi mantap namun menghadapi sejumlah tantangan berat sehingga diperkirakan roda organisasi akan mengalami kesulitan untuk terus berputar bila hanya bertumpu pada strategi sebelumnya. Oleh karenya, organisasi disarankan untuk segera memperbanyak ragam strategi taktisnya.

\section{Kuadran III (negatif, positif)}

Posisi ini menandakan sebuah organisasi yang lemah namun sangat berpeluang. Rekomen-dasi strategi yang diberikan adalah Ubah Strategi, artinya organisasi disarankan untuk mengubah strategi 
sebelumnya. Sebab, strategi yang lama dikhawatirkan sulit untuk dapat menangkap peluang yang ada sekaligus memperbaiki kinerja organisasi.

\section{Kuadran IV (negatif, negatif)}

Posisi ini menandakan sebuah organisasi yang lemah dan menghadapi tantangan besar. Rekomendasi strategi yang diberikan adalah Strategi Bertahan, artinya kondisi internal organisasi berada pada pilihan dilematis. Oleh karenanya organisasi disarankan untuk meenggunakan strategi bertahan, mengendalikan kinerja internal agar tidak semakin terperosok. Strategi ini dipertahankan sambil terus berupaya membenahi diri. hukum, Undang-Undang Dasar 1945 Pasal 18 menjamin adanya Daerah dan wilayah. Sebagai konsekuensinya Pemerintah Pusat diwajibkan melaksanakan politik desentralisasi dan dekonsentrasi, (6) Adanya sejumlah urusan Pemerintah yang bersifat kedaerahan dan memang dapat lebih berdaya guna dan berhasil guna jika dilaksanakan oleh daerah, (7) Daerah mempunyai kemampuan dan perangkat yang cukup memadai untuk menyelenggarakan urusan rumah tangganya maka desentralisasi dilaksanakan dalam penyelenggaraan pemerintahan di daerah.

Terkait dengan ketujuh alasan di atas dan untuk menyelaraskan penyelenggaraan urusan

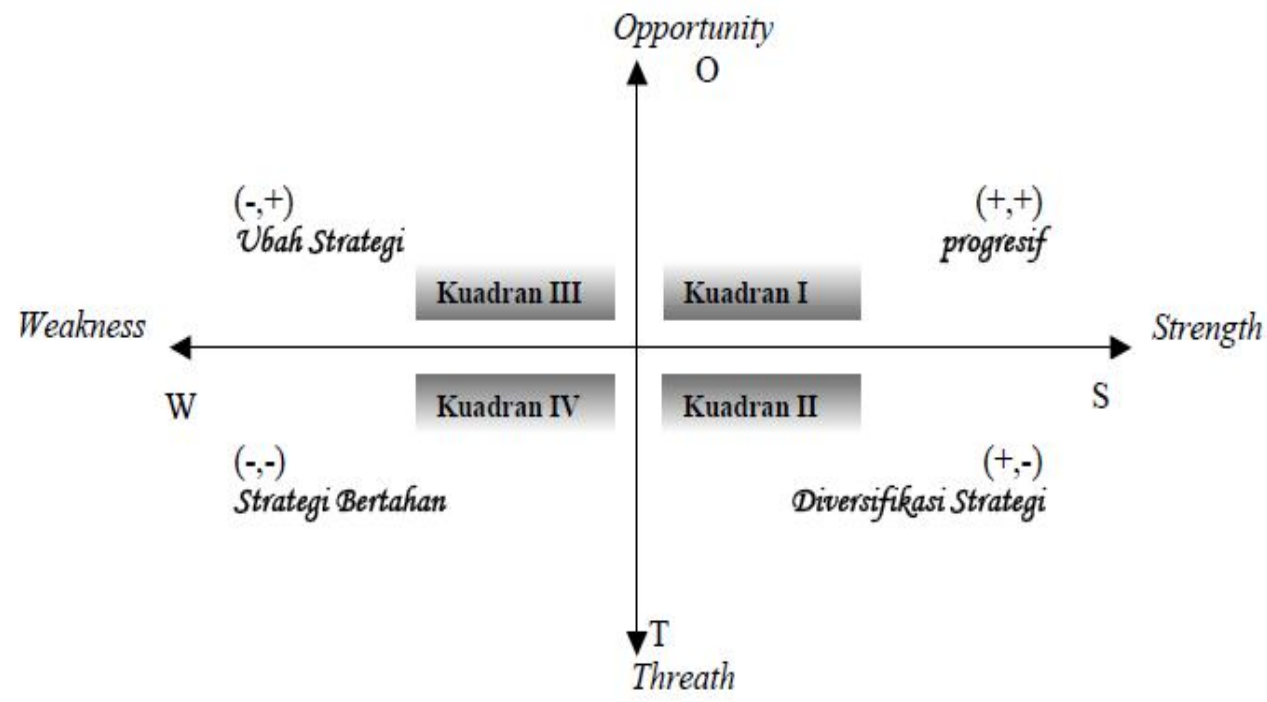

Gambar 1. Posisi Organisasi Menurut Kuadran

\section{Tinjauan Pustaka}

Pada hakekatnya, semua urusan pemerintahan di Indonesia adalah tanggung jawab Pemerintah Pusat (Presiden dan Peran Menteri sebagai pembantunya) untuk menyelenggarakannya. Namun, tidak semua urusan pemerintah Pusat, dan oleh sebab itu Pemerintah Pusat, dan oleh sebab itu Pemerintah Pusat menyerahkan sebagian urusan pemerintah kepada Pemerintah Daerah.

Menurut Surianingrat (1980:10) ada tujuh (7) alasan, sehingga Pemerintah dimaksud, yaitu: (1) kemampuan pemerintah pusat berikut perangkatnya yang ada di daerah terbatas, (2) wilayah negara sangat luas, terdiri dari 3.000 pulau-pulau besar dan kecil, (3) Pemerintah Pusat tidak mungkin mengetahui seluruh dan segala macam kepentingan dan kebutuhan rakyat yang tersebar di seluruh pelosok negara, (4) Hanya rakyat setempatlah yang mengetahui kebutuhan, kepentingan dan masalah yang dihadapi dan hanya mereka yang mengetahui bagaimana cara yang sebaik-baiknya untuk memenuhi kebutuhan tersebut,
(5) Dilihat secara pemerintahan baik di pusat dan daerah, UndangUndang Dasar Negara 1945 Bab VI Pasal 18 dan Pasal 18A, secara umum mengatur pola hubungan kewenangan antara Pemerintah Pusat dan Pemerintah Daerah, dua diantaranya adalah: 1) Negara Kesatuan Republik Indonesia dibagi atas daerah provinsi dan daerah provinsi dibagi atas kabupaten dan kota, yang tiap-tiap provinsi, kabupaten dan kota itu mempunyai pemerintahan daerah, yang diatur dengan UndangUndang; 2) Susunan dan tatacara penyelenggaraan pemerintahan daerah diatur dalam Undang-undang.

Dalam kaitan dengan penegasan UUD NKRI 1945 seperti diutarakan di atas, maka lahirlah Undang-undang yang mengatur tentang Pemerintahan Daerah. Sejak Proklamasi 17 Agustus 1945 hingga saat ini Peraturan Perundang-undangan penyelenggaraan pemerintahan daerah telah mengalami beberapa kali perubahan yaitu: 1) Undang-Undang Nomor 22 Tahun 1948; 2) UndangUndang Nomor 44 Tahun 1950; 3) Undang-Undang Nomor 1 Tahun 1957; 4) Undang-Undang Nomor 6 Tahun 1959; 5) Undang-Undang Nomor 18 Tahun 
1965; 6) Undang-Undang Nomor 5 Tahun 1974; dan 7) Undang-Undang Nomor 22 Tahun 1999 dan yang terakhir dan dijadikan landasan hukum penyelenggaraan pemerintahan daerah saat ini adalah (8) Undang-Undang Nomor 32 Tahun 2004 tentang Pemerintahan Daerah dan Undang-Undang Nomor 33 Tahun 2004 tentang Perimbangan Keuangan antara Pemerintah Pusat dan Pemerintah Daerah.

Pada awal pelaksanaan otonomi daerah dengan paradigma baru sejak Januari 2001 dnegan payung hukum Undang-Undang Nomor 22 Tahun 1999 tentang Pemerintahan Daerah, manajemen Pemerintah Daerah berubah total, salah satunya yang sangat mendasar adalah instansi vertikal yang ada di daerah provinsi, kabupaten dan kota seperti kantor wilayah (Kanwil) di tingkat provinsi dan kantor departemen (Kandep) di tingkat Kabupaten Kota, dilebur menjadi dinas-dinas, yang secara organisatoris berada di bawah dan bertanggung jawab kepada satu dampak dari adanya "kewenangan pemerintahan yang disertai dengan penyerahan dan pengalihan pembiayaan, sarana dan prasarana serta sumberdaya manusia sesuai dengan kewenangan yang diserahkan tersebut (Pasal 8 ayat (1)).

Dalam pengembangan selanjutnya, landasan hukum penyelenggaraan pemerintah daerah saat ini adalah UU No. 32 Tahun 2004, khususnya Pasal 10 ayat (4) menegaskan "Dalam menyelenggarakan urusan pemerintahan sebagaimana dimaksud pada ayat (3) pemerintah menyelenggarakan sendiri atau dapat melimpahkan sebagian urusan pemerintahan kepada perangkat pemerintah atau wakil pemerintah di daerah atau dapat menugaskan kepada pemerintah daerah dan/atau pemerintah desa."

Sedangkan dalam Pasal 12 ayat (2) UU No. 32 Tahun 2004 juga menyebutkan "urusan pemerinahan yang dilimpahkan kepada Gubernur disertai dengan pendanaan sesuai dengan urusan yang didekonsentrasikan". Sebagai tindak lanjut pengaturan pelaksanaan dekonsentrasi dan tugas pembantuan, pemerintah telah menetapkan Peraturan Pemerintah (PP) Nomor 7 Tahun 2008 tentang Dekonsentrasi dan Tugas Pembantuan.

Pengertian Dekonsentrasi dan Tugas Pembantuan sesuai dengan PP No. 7 tahun 2008 ini, yaitu: a. Dekonsentrasi adalah pelimpahan wewenang dari Pemerintah kepada Gubernur di wilayah tertentu, b. Tugas Pembantuan adalah penugasan dari Pemerintah kepada daerah dan/atau desa, dari pemerintah provinsi kepada kabupaten, atau kota dan/atau desa serta dari pemerintah kabupaten atau kota kepada desa untuk melaksanakan tugas tertentu dengan kewajiban melaporkan dan mempertanggungjawabkan pelaksanaannya kepada yang menugaskan. (Pasal 7 angka 10 dan 11).

Pelaksanaan pelimpahan weweang dan penugasan tersebut didasarkan pada prinsip penyelenggaraan dekonsentrasi dan tugas pembantuan yaitu: a. Pemerintah menyelenggarakan sebagian urusan yang menjadi kewenangannya di daerah berdasarkan asas dekonsentrasi.

b. Penyelenggaraan dekonsentrasi dilakukan melalui pelimpahan sebagian urusan pemerintahan yang menjadi kewenangan Kementerian/ Lembaga.

c. Penyelenggaraan tugas pembantuan dilakukan melalui penugasan sebagian urusan pemerintahan yang menjadi kekwenangan pemberi tugas pembantuan dari Pemerintah kepada daerah dan/atau desa, dari pemerintah provinsi kepada kabupaten/kota, dan/ atau desa, serta dari pemerintah kabupaten/kota kepada desa.

d. Kementerian/Lembaga menetapkan sarana, standar, prosedur dan kriteria pelaksanaan kegiatan dekonsentrasi dan tugas pembantuan, (Pasal 2 ayat 1, 2, 3 dan 4).

Sebagai konsekwensi dari pelimpahan wewenang dan penugasan (dekonsentrasi dan tugas pembantuan) tersebut yakni Pemeritnah menyediakan dana dari APBN yang disebut dengan: (1) dana dekonsentrasi adalah dana yang berasal dari APBN yang dilaksanakan oleh Gubernur sebagai wakil Pemerintah yang mencakup semua penerimaan dan pengeluaran dalam rangka pelaksanaan dekonsentrasi, tidak termasuk dana yang dialokasikan untuk instansi vertikal pusat di daerah, (2) Dana tugas pembantuan adalah dana yang berasal dari APBN yang dilaksanakan oleh daerah dan desa yang mencakup semua penerimaan dan pengeluaran dalam rangka pelaksanaan tugas pembantuan (Pasal 1 angka 14 dan 15).

Berdasarkan penjelasan di atas, nampak bahwa dalam pelaksanaan pemerintahan daerah "asas desentralisasi dilaksanakan bersama-sama dengan asas tugas pembantuan; (Sugianto, 1990:71). Pelaksanaan pemerintah daerah dengan ketiga asas tersebut secara bersama-sama, menurut Sugianto 1990: 88) "memberikan tempat yang sama penting dan proporsional bagi ketiga asas penyelenggaraan pemerintah di daerah yanki: desentralisasi, dekonsentrasi dan tugas pembantuan”.

\section{HASIL DAN PEMBAHASAN}

\section{Studi Pengelolaan Dana Dekonsentrasi dan Tugas Pembantuan}

Pengelolaan dana dekonsentrasi dan tugas pembantuan dalam studi ini adalah merupakan konsekwensi dari pelimpahan wewenang dan penugasan yang didanai dari APBN dan dilaksanakan Gubernur dan Bupati/Walikota. Bagaimana progres pengelolaan tersebut, maka perlu dilakukan evaluasi.

Secara umum pengertian evaluasi menurut Badudu dan Zain (1994) dijelaskan, bahwa evaluasi adalah penilaian. Mengevaluasi adalah menilai, memeriksa untuk menilai. Badudu dan Zain 
memecahkan evaluasi yakni: "evaluasi pekerjaan yang sudah dilakukan, bagaimana hasilnya (cukup, baik atau buruk)". Contoh lain: "mengevaluasi kemajuan siswa yaitu menilai agar diketahui bagaimana kemajuan itu".

Kata "evaluasi" tidak berdiri sendiri, sering dipadankan dengan kata lain, misalnya, Evaluasi Penyelenggaraan Pemerintahan Daerah adalah suatu proses pengumpulan dan analisis data secara sistematis terhadap kinerja penyelenggaraan pemerintah, kemampuan penyelenggaraan otonomi daerah dan kelengkapan aspek-aspek penyelenggaraan pemerintah pada daerah yang baru dibentuk, (PP No.6/2000, angka 13).

Berdasarkan pengertian tersebut, tidak secara eksplisit evaluasi dimaknai dengan "menilai" tetapi didahului dengan suatu proses pengumpulan data. Hasil dari pengumpulan data yang secara sistematis itulah ada analisis atau menguraikan dan dari hasil analisis atau pengenalan itulah tergambar bagaimana: (1) kemampuan (mampu atau tidak mampu) suatu daerah itu menyelenggarakan otonomi daerah, (2) kinerja atas penyelenggaraan pemerintahan daerah itu, baik atau buruk, meningkat atau menurun.

Pengertian evaluasi menurut Scriven (1969) dalam Dunn (2003:607) adalah "merupakan persoalan fakta dan logika dan lebih penting dari yang paling pentng". Artinya, bahwa melaksanaan atau memuat evaluasi bukan persoalan opini atau selera, tetapi evaluasi untuk menjawab apa yang terjadi, bagaimana dan mengapa terjadi perbedaan antara kebijakan yang ditetapkan dengan fakta di lapangan (hasil kebijakan).

Dunn (2003) secara lebih luas menjelaskan mengenai evaluasi yakni:

a. Secara umum istilah evaluasi dapat disamakan dengan penaksiran (appraisal), pemberian angka (rating) dan penilaian assessment).

b. Dalam arti yang lebih spesifik, evaluasi berkenan dengan produksi informasi mengenai nilai atau manfaat hasil kebijakan. Ketika hasil kebijakan pada kenyataannya mempunyai nilai, hal ini karena hasil tersebut memberi sumbangan pada tujuan dan sasaran. Dalam hal ini, dapat dikatakan bahwa kebijakan atau program telah mencapai tingkat kinerja yang bermakna, yang berarti bahwa masalah-masalah kebijakan dibuat jelas atau di atas.

c. Gambaran utama evaluasi adalah bahwa evaluasi menghasilkan tuntutan-tuntutan yang bersifat evaluatif. Karena itu evaluasi mempunyai sejumlah karakteristik, yang membedakannya dari metode analisis kebijakan lainnya, yaitu:

1) Fokus nilai evaluasi berbeda dengan pemantauan, dipusatkan pada penilaian yang menyangkut keperluan atau nilai dari sesuatu kebijakan dan program. Evaluasi terutama merupakan usaha untuk "menentukan manfaat atau kegunaan sosial kebijakan atau program, dan bukan untuk sekedar usaha untuk mengumpulkan informasi mengenai hasil aksi kebijakan yang terantisipasi atau tidak terantipasi. Karena ketepatan tujuan dan sasaran kebijaksanaan dapat selalu dipertanyakan evaluasi mencakup prosedur untuk mengevaluasi tujuan-tujuan dan sasaran itu sendiri.

2) Independensi Fakta Nilai. Tuntutan evaluasi tergantung, baik pada "fakta" maupun "nilai". Untuk menyatakan bahwa kebijakan atau program tertentu telah mencapai tingkat kinerja yang tertinggi atau erndah diperlukan, tidak hanya hasilhasil kebijakan berharga bagi sejumlah individu, kelompok atau seluruh masyarakat. Untuk mengatakan demikian, harus didukung oleh bukti bahwa hasilhasil kebijakan secara aktual merupakan konsekuensi dan aksi-aksi yang dilakukan untuk memecahkan masalah tertentu. Oleh karena itu, pemantauan merupakan prasyarat bagi evaluasi.

3) Orientasi masa kini dan masa lampau. Tentukan evaluatif, berbeda dengan tuntutan-tuntutan advokatif, yang diarahkan pada hasil sekarang dan masa lalu, ketimbang hasil masa depan. Evaluasi bersifat retrospektif dan setelah aksi-aksi dilakukan (ex post). Rekomendasi yang juga mencakup premis-premis, bersifat prospektif dan dibuat sebelum aksi-aksi dilakukan (exante).

4) Dualitas nilai. Nilai-nilai yang mendasari tuntutan evaluasi mempunyai kualitas ganda, karena dipandang sebagai tujuan dan sekaligus care. Evaluasi sama dengan rekomendasi sejarah berkenaan dengan nilai yang ada (misalnya kesehatan) dapat dianggap sebagai instrinsik (diperlukan bagi dirinya) atau pun ekstrinsik diperlukan karena hal itu mempengaruhi tujuan-tujuan lain.

Nilai-nilai sering ditata di dalam suatu hirarkhi yag merefleksikan kepentingan relatif dan saling ketergantungan antar tujuan dan sasaran.

d. Fungsi Evaluasi Kebijakan.

Telah diutarakan di atas, bahwa evaluasi itu salah satunya dapat disamakan dengan penilaian (assesment). Dengan demikian, maka penilaian kebijakan (Islam 1929) adalah merupakan langkah terakhir dari suatu proses kebijakan. Penilaian kebijakan tidak hanya dilakukan dengan mengikuti, aktivitas-aktivitas sebelumnya, yaitu pengesahan dan pelaksanaan kebijakan, tetapi dapat terjadi pada seluruh 
aktivitas-aktivitas fungsional yang lain dalam proses kebijakan. Dengan demikian, penilaian kebijakan dapat mencakup tentang: Isi kebijakan, pelaksanaan kebijakan, dan lampu kebijakan dan dampak kebijakan. Jadi, pemikiran kebijakan dapat dilakukan pada fase, penurunan masalahnya, formulasi usulan kebijakan, implementasi legistimasi kebijakan. Oleh karena itu, menurut Dunn (2003) fungsi evaluasi kebijakan itu, pertama, memberi informasi yang valid dan dapat dipercaya mengenai kinerja kebijakan yaitu seberapa jauh kebutuhan, nilai dan kesempatan telah dapat dicapai melalui tindakan publik atau seberapa jauh tujuan-tujuan tertentu dan target tertentu tidak dicapai. Kedua, memberi sumbangan pada klarifikasi dan kritik terhadap nilai-nilai yang mendasari pemilihan tujuan dan target.

e. Pendekatan dalam evaluasi kebijakan.

Menurut Dunn (2003: 613-619) ada 3 (tiga) pendekatan dalam melakukan evaluasi kebijakan. Ketiga pendekatan tersebut secara ringkas dijelaskan sebagai berikut :

1. Evaluasi Semu (Psaude Evaluation) adalah pendekatan yang menggunakan metode-metode deskriptif untuk menghasilkan informasi yang valid dan dipercaya mengenai hasil kebijakan, tanpa berusaha untuk menanyakan tentang manfaat atau nilai dari hasil-hasil tersebut terhadap individu, kelompok atau masyarakat secara keseluruhan.Asumsi utama dari evaluasi semu adalah bahwa ukuran tentang manfaat atau nilai merupakan sesuatu yang dapat terbukti sendiri (self-evident) atau tidak kontroversial.

2. Evaluasi Formal (Formal Education) adalah meruakan pendekatan yang menggunakan metode deskriptif untuk menghasilkan informasi yang valid dan cepat dipercaya mengenai hasil-hasil kebijakan, tetapi mengevaluasi hasil tersebut atas dasar tujuan program kebiakan yang telah diumumkan secara formal oleh pembuat kebijakan dan administrator program. Asumsi utama dari evaluasi formal adalah bahwa tujuan dan target diumumkan secara formal sebagai ukuran yang tepat untuk manfaat atau nilai kebijakan program.

3. Evaluasi Keputusan Teoritis. Evaluasi Keputusan Teoritis (Decision Theoritic Evaluation) adalah pendekatan yang menggunakan metode-metode deskriptif untuk menghasilkan informasi yang dapat dipertanggungjawabkan dan valid mengenai hasil-hasil kebijakan yang secara eksplisit dinilai oleh berbagai macam pelaku kebijakan. Perbedaan pokok antara evaluasi teoritis keputusan di satu sisi, dan evaluasi semua dan evaluasi formal di sisi lainnya, adalah bahwa evaluasi keputusan teoritis berusaha untuk memunculkan dan membuat eksplisit tujuan dan target dari pelaku kebijakan baik yang tersembunyi atau dinyatakan.

Bertitik tolak dari paparan dan penjelasan seperti dikemukakan, maka evaluasi pengelolaan dana dekonsentrasi dan tugas pembantuan dalam kajian ini, maka Evaluasi dana dekonsentrasi dan Tugas Pembantuan adalah suatu proses pengumpulan dan analisis data secara sistemastis terhadap pengelolaan atau pemanfaatan dana yang berasal dari dana APBN, yang dilaksanakan oleh gubernur sebagai wakil pemerintah dan yang dilaksanakan oleh pemerintah Provinsi, Kabupaten/Kota dan atau desa. Dilihat dari sudut perencanaan dan penganggaran, pelaksanaan dan pelaporan dalam satu tahun anggaran di lingkungan Kemendagri.

\section{Analisis}

Kondisi pelaksanaan dan pelaporan kegiatan dekonsentrasi dan tugas pembantuan di daerah digambarkan dengan menggunakan skala Likert, seperti pada Tabel 3 berupa hasil penilaian di masing-masing lokasi sampel studi.

Berdasarkan data dari Tabel 4 didapatkan bahwa untuk aspek manajerial untuk masing-masing lokasi studi masuk dalam kategori sangat baik (provinsi Sulut dan DI Yogyakarta) dan baik (Provinsi Banten dan Jateng). Berdasarkan aspek akuntabilitas Provinsi Sulut dan DI Yogyakarta masuk dalam kategori cukup baik dan Provinsi Banten dan Jateng masuk dalam kategori kurang baik.

Perhitungan terhadap kondisi pelaksanaan dan pelaporan dengan menggunakan Skala Likert diperoleh hasil bahwa yang mendapatkan nilai yang kecil yaitu variable laporan realisasi anggaran dalam kegiatan dekon TP yang dilaporkan dan penatusahaan barang dalam kegiatan dekon TP yang dilaporkan. Oleh karena itu diperlukan sebuah perbaikan system terhadap laporan realisasi dan penatausahaan barang dekonsentrasi dan tugas pembantuan.

Beberapa kendala dalam penyusunan perencanaan dan penganggaran kegiatan dekonsentrasi dan tugas pembantuan adalah sebagai berikut:

a. Dalam pelimpahan dan penugasan urusan Kemendagri melalui DK-TP belum optimal

b. Dalam menyusun perencanaan dan penganggaran kegiatan DK-TP masih ada yang menggunakan mekanisme diluar musrenbangnas melainkan melalui usulan non formal lewat surat-menyurat/proposal

c. Penyerahan DIPA kepada SKPD sering terlambat yang berakibat pada pencairan dana dekon/TP terlambat 
Tabel 3. Pelaksanaan dan Pelaporan di Masing-Masing Lokasi Studi

\begin{tabular}{|c|c|c|c|c|c|}
\hline \multirow{2}{*}{ Aspek } & \multirow{2}{*}{ Variabel } & \multicolumn{4}{|c|}{ Provinsi } \\
\hline & & Sulut & Banten & DIY & Jateng \\
\hline \multirow[t]{4}{*}{$\begin{array}{l}\text { Mana- } \\
\text { jerial }\end{array}$} & $\begin{array}{l}\text { Realisasi penyerapan dana dapat } \\
\text { dipertanggungjawabkan }\end{array}$ & $\begin{array}{l}\text { Sangat dapat } \\
\text { dipertanggung } \\
\text { jawabkan }\end{array}$ & $\begin{array}{l}\text { Kurang dpt } \\
\text { dipertanggung } \\
\text { jawabkan }\end{array}$ & $\begin{array}{l}\text { Sangat dapat } \\
\text { dipertanggung } \\
\text { jawabkan }\end{array}$ & $\begin{array}{l}\text { Cukup dapat } \\
\text { dipertanggu } \\
\text { ng jawabkan }\end{array}$ \\
\hline & $\begin{array}{l}\text { Penyelenggaraan program dan } \\
\text { kegiatan dekon TP }\end{array}$ & $\begin{array}{l}\text { Tercapai sesuai } \\
\text { target }\end{array}$ & $\begin{array}{l}\text { Cukup } \\
\text { tercapai sesuai } \\
\text { target }\end{array}$ & $\begin{array}{l}\text { Tercapai } \\
\text { sesuai target }\end{array}$ & $\begin{array}{l}\text { Tercapai } \\
\text { sesuai target }\end{array}$ \\
\hline & $\begin{array}{l}\text { Kendala yang dihadapi dalam } \\
\text { kegiatan dekon/TP yang dilaporkan }\end{array}$ & $\begin{array}{l}\text { Selalu } \\
\text { dilaporkan }\end{array}$ & $\begin{array}{l}\text { Selalu } \\
\text { dilaporkan }\end{array}$ & $\begin{array}{l}\text { Selalu } \\
\text { dilaporkan }\end{array}$ & $\begin{array}{l}\text { Selalu } \\
\text { dilaporkan }\end{array}$ \\
\hline & $\begin{array}{l}\text { Mengatasi masalah yang dihadapi } \\
\text { dalam kegiatan dekon/TP yang } \\
\text { dilaporkan (menyampaikan saran } \\
\text { dan tindak lanjut kepada } \\
\text { Kemendagri) }\end{array}$ & Dilaporkan & Dilaporkan & Dilaporkan & Dilaporkan \\
\hline \multirow[t]{4}{*}{$\begin{array}{l}\text { Akun- } \\
\text { tabilitas }\end{array}$} & $\begin{array}{l}\text { Laporan realisasi anggaran dalam } \\
\text { kegiatan dekon TP yang dilaporkan }\end{array}$ & $\begin{array}{l}\text { Cukup } \\
\text { dilaporkan }\end{array}$ & $\begin{array}{l}\text { Kurang } \\
\text { dilaporkan }\end{array}$ & $\begin{array}{l}\text { Cukup } \\
\text { dilaporkan }\end{array}$ & $\begin{array}{l}\text { Kurang } \\
\text { dilaporkan }\end{array}$ \\
\hline & $\begin{array}{l}\text { Neraca laporan realisasi anggaran } \\
\text { dalam kegiatan dekon TP yang } \\
\text { dilaporkan (membuat neraca dan } \\
\text { dilaporkan) }\end{array}$ & $\begin{array}{l}\text { Cukup membuat } \\
\text { neraca yang } \\
\text { dilaporkan tiap } \\
\text { bulan }\end{array}$ & $\begin{array}{l}\text { Cukup } \\
\text { membuat } \\
\text { neraca yang } \\
\text { dilaporkan } \\
\text { tiap bulan }\end{array}$ & $\begin{array}{l}\text { Cukup } \\
\text { membuat } \\
\text { neraca yang } \\
\text { dilaporkan } \\
\text { tiap bulan }\end{array}$ & $\begin{array}{l}\text { Cukup } \\
\text { membuat } \\
\text { neraca yang } \\
\text { dilaporkan } \\
\text { tiap bulan }\end{array}$ \\
\hline & $\begin{array}{l}\text { Catatan atas laporan keuangan } \\
\text { dalam kegiatan dekon TP yang } \\
\text { dilaporkan }\end{array}$ & $\begin{array}{l}\text { Catatan atas } \\
\text { laporan } \\
\text { keuangan cukup } \\
\text { dibuat dan } \\
\text { dilaporkan }\end{array}$ & $\begin{array}{l}\text { Catatan atas } \\
\text { laporan } \\
\text { keuangan } \\
\text { cukup dibuat } \\
\text { dan } \\
\text { dilaporkan }\end{array}$ & $\begin{array}{l}\text { Catatan atas } \\
\text { laporan } \\
\text { keuangan } \\
\text { cukup dibuat } \\
\text { dan } \\
\text { dilaporkan }\end{array}$ & $\begin{array}{l}\text { Catatan atas } \\
\text { laporan } \\
\text { keuagan } \\
\text { cukup } \\
\text { dibuat dan } \\
\text { dilaporkn }\end{array}$ \\
\hline & $\begin{array}{l}\text { Penatusahaan barang dalam } \\
\text { kegiatan dekon TP yang dilaporkan }\end{array}$ & $\begin{array}{l}\text { Cukup dibuat } \\
\text { secara rutin }\end{array}$ & $\begin{array}{l}\text { Kurang dibuat } \\
\text { secara rutin }\end{array}$ & $\begin{array}{l}\text { Cukup dibuat } \\
\text { secara rutin }\end{array}$ & $\begin{array}{l}\text { Kurang } \\
\text { dibuat } \\
\text { secara rutin }\end{array}$ \\
\hline
\end{tabular}

Sumber: Hasil Penelitian Puslitbang Keuda. Data Diolah, 2011.

Tabel 4. Penilaian Likert Scale Pelaksanaan dan Pelaporan di Masing-Masing Lokasi Studi

\begin{tabular}{|c|c|c|c|c|c|}
\hline \multirow{2}{*}{$\begin{array}{lr} & \text { Variabel } \\
\text { Aspek Manajerial } & \\
\end{array}$} & \multicolumn{4}{|c|}{ Provinsi } & \multirow{2}{*}{$\begin{array}{l}\text { Rata- } \\
\text { Rata }\end{array}$} \\
\hline & Sulut & Banten & DIY & Jateng & \\
\hline $\begin{array}{l}\text { Realisasi penyerapan dana dapat } \\
\text { dipertanggungjawabkan }\end{array}$ & 5 & 2 & 5 & 3 & 3,75 \\
\hline penyelenggaraan program dan kegiatan dekon TP & 4 & 3 & 4 & 4 & 3,75 \\
\hline $\begin{array}{l}\text { Kendala yang dihadapi dalam kegiatan dekon/TP yang } \\
\text { dilaporkan }\end{array}$ & 5 & 5 & 5 & 5 & 5 \\
\hline $\begin{array}{l}\text { mengatasi masalah yang dihadapi dalam kegiatan } \\
\text { dekon/TP yang dilaporkan (menyampaikan saran dan } \\
\text { tindak lanjut kepada Kemendagri) }\end{array}$ & 4 & 4 & 4 & 4 & 4 \\
\hline Rata-rata & 4,5 & 3,5 & 4,5 & 4 & 4,125 \\
\hline Kriteria & sangat baik & baik & $\begin{array}{c}\text { sangat } \\
\text { baik }\end{array}$ & baik & \\
\hline Aspek Akuntabilitas & Sulut & Banten & DIY & Jateng & $\begin{array}{l}\text { Rata- } \\
\text { Rata }\end{array}$ \\
\hline $\begin{array}{l}\text { laporan realisasi anggaran dalam kegiatan dekon TP } \\
\text { yang dilaporkan }\end{array}$ & 3 & 2 & 3 & 2 & 2,5 \\
\hline $\begin{array}{l}\text { neraca laporan realisasi anggaran dalam kegiatan } \\
\text { dekon TP yang dilaporkan (membuat neraca dan } \\
\text { dilaporkan) }\end{array}$ & 3 & 3 & 3 & 3 & 3 \\
\hline $\begin{array}{l}\text { catatan atas laporan keuangan dalam kegiatan dekon } \\
\text { TP yang dilaporkan a }\end{array}$ & 3 & 3 & 3 & 3 & 3 \\
\hline $\begin{array}{l}\text { penatusahaan barang dalam kegiatan dekon TP yang } \\
\text { dilaporkan }\end{array}$ & 3 & 2 & 3 & 2 & 2,5 \\
\hline Rata-rata & 3 & 2,5 & 3 & 2,5 & 2,75 \\
\hline Kriteria & cukup baik & $\begin{array}{c}\text { kurang } \\
\text { baik }\end{array}$ & $\begin{array}{c}\text { cukup } \\
\text { baik }\end{array}$ & $\begin{array}{c}\text { kurang } \\
\text { baik }\end{array}$ & \\
\hline
\end{tabular}

Sumber: Hasil Penelitian Puslitbang Keuda. Data Diolah, 2011. 
SKPD terlambat.

Untuk mengatahui kondisi kegiatan dekonsentrasi dan tugas pembantuan, dilihat dengan menggunakan analisis SWOT yaitu dengan membandingkan antara kondisi internal (kekuatan dan kelemahan) dan eksternal (peluang dan tantangan). Dengan menggunakan analisis keruangan (SWOT) dihitung antara rumus:

$$
\begin{array}{lll}
\text { Kekuatan }- \text { Kelemahan } & =1,60-1,27=0,33 \\
\text { Peluang - Tantangan } & =1,5-1,58=-0,08
\end{array}
$$

Antara kedua parameter tersebut diperoleh gambaran strategi pada Gambar 7 . a. melakukan sosialisasi dan bintek tentang proses penyusunan program kegiatan dan anggaran.

b. percepatan revisi UU 32 Tahun 2004 beserta peraturan pelaksanaannya.

c. peningkatan pemahaman SDM pelaksanan DKTP terhadap PMK Nomor 156/PMK.07/2008 tentang Pedoman Pengelolaan Dana DK/TP melalui sosialisasi dan bintek.

d. perlu melakukan penyempurnaan Peraturan Pemerintah yang mengatur tentang Dekonsentrasi dan Tugas Pembantuan, khususnya memasukkan pasal yang mengatur tentang kewajiban Kementerian/ Lembaga untuk melakukan penatausahaan BMN hasil kegiatan Dekonsentrasi dan Tugas Pembantuan,

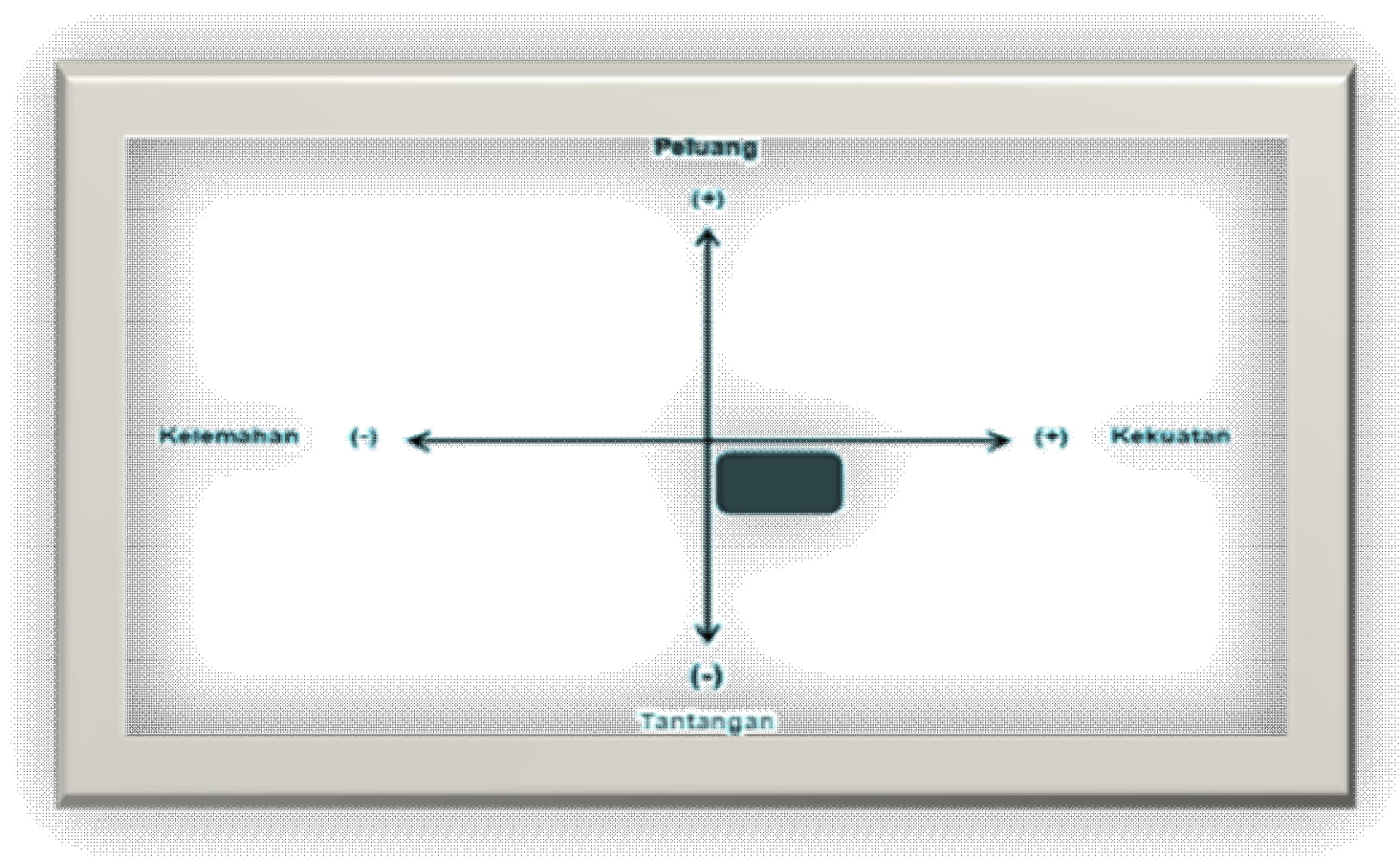

Gambar 7. Parameter Kondisi Eksternal dan Internal Berdasarkan Analisis Keruangan SWOT.

Posisi hasil analisis keruangan (SWOT) menandakan sebuah organisasi yang kuat namun menghadapi tantangan yang besar. Rekomendasi strategi yang diberikan adalah Diversifikasi Strategi, artinya Kemendagri dalam kondisi mantap namun menghadapi sejumlah tantangan berat, sehingga diperkirakan Kemendagri akan mengalami kesulitan untuk terus berputar bila hanya bertumpu pada strategi sebelumnya. Oleh karenya, Kemendagri disarankan untuk segera memperbanyak ragam strategi taktisnya.

Strategi perbaikan pelaksanaan kegiatan DK-TP di lingkungan Kemendagri didapatkan dengan cara memadukan antara kekuatan dan tantangan sehubungan dengan hasil analisis SWOT. Strategi-strategi tersebut adalah sebagai berikut: sebelum BMN tersebut dihibahkan kepada daerah.

e. para stakeholder/pemangku kepentingan yang terkait dengan pelaksanaan Dekonsentrasi dan Tugas Pembantuan di lingkungan Kemendagri untuk mematuhi peraturan perundang-undangan khususnya terkait dengan perencanaan dan penganggaran, pelaksanaan serta pelaporan.

f. segera membentuk Tim ad Hock untuk menangani percepatan penyelesaian penetapan status BMN yang berasal dari dana Dekonsentrasi dan Tugas Pembantuan di lingkungan Kemendagri yang akan berakhir akhir tahun 2013.

g. optimalisasi koordinasi DK-TP dengan penyelenggaraan urusan pemerintahan daerah. 
Tabel 5. Hasil Perhitungan Faktor Internal

\begin{tabular}{|c|c|c|c|}
\hline \multicolumn{4}{|l|}{ Faktor Internal } \\
\hline Kekuatan & Bobot & Rating & Total \\
\hline $\begin{array}{l}\text { Pelaksanaan DK-TP di daerah secara umum telah diatur dan didukung dengan } \\
\text { peraturan UU No. } 32 \text { Th. } 2004 \text {, UU No. } 33 \text { Th. 2004, PP. No. } 7 \text { Th. } 2008 \text { dan } \\
\text { peraturan pendukung lainnya }\end{array}$ & 0.083 & 3 & 0.25 \\
\hline $\begin{array}{l}\text { Aspek perencanaan dalam proses penyusunan program, kegiatan dan anggaran telah } \\
\text { mengacu pada RKP dan dituangkan dalam Renja-KL }\end{array}$ & 0.083 & 3 & 0.25 \\
\hline $\begin{array}{l}\text { Aspek penganggaran telah mengikuti ketentuan yang mengatur tentang penyusunan dan } \\
\text { penelaahan RKA-KL dan DIPA berdasarkan PP. No.7 Th. } 2008\end{array}$ & 0.083 & 3 & 0.25 \\
\hline $\begin{array}{l}\text { Laporan manajerial dan di laporan data bentuk Form C dari PP. No. } 39 \text { Th. } 2006 \text { dan } \\
\text { Laporan Akuntabilitas dalam bentuk aplikasi SAI }\end{array}$ & 0.083 & 3 & 0.25 \\
\hline $\begin{array}{l}\text { Konsistensi pemerintah untuk melaksanakan DK-TP yang diturunkan dalam UU No.33 } \\
\text { Th. } 2004 \text { dan PP. } 7 \text { Th. } 2008 \text { dan peraturan pendukung lainnya }\end{array}$ & 0.083 & 3 & 0.25 \\
\hline Komitmen Pemerintah pusat untuk peningkatan pelaksanaan DK-TP & 0.083 & 4 & 0.33 \\
\hline Jumlah & 0.5 & & 1.6 \\
\hline Kelemahan & Bobot & Rating & Total \\
\hline $\begin{array}{l}\text { Kurangnya dokumen pendukung untuk keperluan memperoleh persetujuan hibah barang } \\
\text { milik negara }\end{array}$ & 0.04 & 2 & 0.077 \\
\hline Sarana dan prasarana untuk pelaporan dan monev kurang memadai & 0.04 & 3 & 0.115 \\
\hline Anggaran sebagai penunjang utama pengelolaan pelaporan dan monev masih terbatas & 0.04 & 3 & 0.115 \\
\hline $\begin{array}{l}\text { Aset tetap DK/TP yang dilaporkan dalam LKPP } 2010 \text { belum seluruhnya dilakukan } \\
\text { inventarisasi dan penilaian sebesar Rp849.871.311,00 pada } 11 \text { SKPD di } 8 \text { Provinsi }\end{array}$ & 0.04 & 3 & 0.115 \\
\hline $\begin{array}{l}\text { Sampai dengan penyusunan Laporan Keuangan Tahun 2010 Audited, Aset } \\
\text { Dekon/TP/UB yang telah selesai dihibahkan kepada pemerintah daerah sebesar } \\
\text { Rp56.437.725.807,00 sedangkan Aset Dekon/TP/UB sebesar Rp1.367.976.022.542,00 } \\
\text { masih tercantum dalam neraca (belum dihibahkan). Adanya usaha Kemendagri terhadap } \\
\text { Aset Dekon/TP/UB tersebut untuk segera diproses dihibahkan ke pemerintah daerah. }\end{array}$ & 0.04 & 3 & 0.115 \\
\hline $\begin{array}{l}\text { Belum ada kebijakan yang mengatur mekanisme koordinasi, pencatatan, serta } \\
\text { pelaporan belanja dan barang milik negara dari dana DK dan TP, baik di lingkungan } \\
\text { Kemendagri, Pemda, dan koordinasi diantara keduanya, }\end{array}$ & 0.04 & 2 & 0.077 \\
\hline $\begin{array}{l}\text { Unit Eselon } 1 \text { yang mempunyai anggaran Dana DK dan TP agar melaksanakan } \\
\text { sosialisasi SAI kepada SKPD Pelaksana Dana DK dan TP; }\end{array}$ & 0.04 & 3 & 0.115 \\
\hline $\begin{array}{l}\text { Pertimbangan Mendagri kepada Presiden terhadap DKTP K/L dalam } \\
\text { melimpahkan/menugaskan urusan belum berjalan sebagaimana mestinya }\end{array}$ & 0.04 & 2 & 0.077 \\
\hline $\begin{array}{l}\text { Kriteria lokasi dan alokasi baik umum maupun teknis belum memadai atau belum } \\
\text { diterapkan secara optimal; }\end{array}$ & 0.04 & 3 & 0.115 \\
\hline $\begin{array}{l}\text { Prinsip efisiensi dan efektifitas masih perlu ditingkatkan dengan menggunakan } \\
\text { parameter yang jelas; }\end{array}$ & 0.04 & 2 & 0.077 \\
\hline konsistensinya dengan pencapaian sasaran proritas nasional masih kurang & 0.04 & 2 & 0.077 \\
\hline $\begin{array}{l}\text { Kegiatan Dekonsentrasi dan Tugas Pembantuan K/L ke daerah dan Instansi vertikal } \\
\text { tidak dikoordinasikan secara baik dengan Pemerintah Daerah; }\end{array}$ & 0.04 & 3 & 0.115 \\
\hline Belum optimalnya pelaksanaan pemantauan dan evaluasi; & 0.04 & 2 & 0.077 \\
\hline Jumlah & 0.50 & & 1.27 \\
\hline
\end{tabular}

Sumber: Hasil Penelitian Puslitbang Keuda. Data Diolah, 2011.

h. pemerintah provinsi dan kabupaten/kota untuk lebih mengoptimalkan dan mengefektifkan Tim Koordinasi Penyelenggaraan Dekonsentrasi dan Tugas Pembantuan yang ada di Provinsi, dalam melakukan sinkronisasi, penyiapan perangkat, koordinasi, pembinaan dan pengawasan serta pelaporan kegiatan DK-TP.

i. meningkatkan kualitas dan kuantitas Aparatur, khususnya yang menguasai pertanggungjawaban dan pelaporan keuangan (manajerial dan akuntabilitas).

j. meningkatkan kualitas dan kuantitas Aparatur, khususnya yang menguasai pertanggungjawaban dan pelaporan keuangan (manajerial dan akuntabilitas).

k. pemerintah provinsi dan kabupaten/ kota untuk lebih mengoptimalkan dan mengefektifkan Tim
Koordinasi Penyelenggaraan Dekonsentrasi dan Tugas Pembantuan yang ada di Provinsi, dalam melakukan sinkronisasi, penyiapan perangkat, koordinasi, pembinaan dan pengawasan serta pelaporan kegiatan DK-TP.

1. pemerintah provinsi, kabupaten/kota agar mendukung Tim Ad Hock untuk menangani percepatan penyelesaian penetapan status BMN yang berasal dari dana Dekonsentrasi dan Tugas Pembantuan di lingkungan Kemendagri.

\section{SIMPULAN}

1. Pelaksanaan kegiatan yang dibiayai dari dana Dekonsentrasi dan Tugas Pembantuan di lingkungan Kemendagri belum sepenuhnya mematuhi peraturan perundang-undangan, 
Tabel 6. Perhitungan Faktor Eksternal

\begin{tabular}{lccc}
\hline \multicolumn{1}{c}{ Peluang } & & & \\
\hline & Baktor Eksternal & Rating & Total \\
\hline Komitmen daerah terhadap pelaksanaan DK/TP & 0.125 & 4 & 0.5 \\
\hline pemberian DK-TP didaerah pemekaran & 0.125 & 3 & 0.375 \\
\hline APBD yang terbatas & 0.125 & 2 & 0.25 \\
\hline potensi lokal yang masih perlu dikembangkan & 0.125 & 3 & 0.375 \\
\hline \multicolumn{1}{c}{ Tantangan } & 0.5 & 12 & 1.5 \\
\hline \multicolumn{1}{c}{ Jumlah } & Bobot & Rating & Total \\
\hline Kualitas pelaksana/SDM DK-TP di SKPD belum optimal & 0.083 & 0.333 \\
\hline adanya rencana revisi terhadap UU no 32 tahun 2004 tentang Pemerintahan Daerah & 0.083 & 2 & 0.167 \\
\hline $\begin{array}{l}\text { Pelaporan keuangan dan BMN DK-TP oleh SKPD masih lemah dan belum sesuai } \\
\text { dengan PMK Nomor 156/PMK.07/2008 tentang Pedoman Pengelolaan Dana DK/TP }\end{array}$ & 0.083 & 4 & 0.333 \\
\hline $\begin{array}{l}\text { Belum optimalnya kebijakan yang mengatur mekanisme koordinasi, pencatatan, serta } \\
\text { pelaporan belanja dan barang milik negara dari dana DK dan TP, baik di lingkungan }\end{array}$ & 0.083 & 3 & 0.250 \\
$\begin{array}{l}\text { Kemendagri, Pemda, dan koordinasi diantara keduanya, } \\
\text { Sinkronisasi DK-TP dengan penyelenggaraan urusan pemerintahan daerah belum } \\
\text { optimal; }\end{array}$ & 0.083 & 3 & 0.250 \\
\hline $\begin{array}{l}\text { Hasil pemeriksaan BPK atas pelaksanaan program kegiatan DK-TP oleh SKPD belum } \\
\text { transparan dan akuntabel }\end{array}$ & 0.083 & 3 & 0.250 \\
\hline
\end{tabular}

Sumber: Hasil Penelitian Puslitbang Keuda. Data Diolah, 2011.

khususnya terkait dengan perencanaan dan penganggaran, pelaksanaan, serta pelaporan.

2. Terdapat hasil kegiatan Dekonsentrasi dan Tugas Pembantuan di lingkungan Kemendagri yang berupa aset dari tahun 2003 s/d 2008, 2009 dan 2010 senilai Rp 1.390.519.873.741,00 dan yang baru dihibahkan senilai Rp 52.149.529.526,63 $(3,75 \%)$ sedangkan sisanya belum ditetapkan statusnya, hal ini merupakan tanggung jawab Menteri Dalam Negeri selaku Pengguna Anggaran.

3. Kebijakan kegiatan Dekonsentrasi dan Tugas Pembantuan di lingkungan Kemendagri berpeluang untuk dilanjutkan dengan berbagai penyempurnaan.

\section{DAFTAR PUSTAKA}

Sugianto, 1990. Membedah Otonomi Daerah Suatu Evaluasi Atas UU No. 5 Tahun 1974 tentang Pokok-pokok Pemerintahan di Daerah. Balitbang Departemen Dalam Negeri. Merangkai Masa Depan Otonomi Daerah. Kumpulan Makalah.

Sugiono 1993, Metode Penelitian Kuantitatif, Kualitatif $R \& D$. Bandung: Alfabeto. Cet. ke-5.

Surianingrat, Bayu, 1980. Mengenal Ilmu Pemerintahan. Jakarta: Aksara Baru. Cetakan pertama.

William Dunn, 2000. Analisis Kebijakan Publik. Terjemahan Gadjah Mada Uiversity Press. Cetakan ke III. Yogyakarta.

\section{Sumber Perundang-Undangan}

Peraturan Menteri Keuangan Nomor 156 Tahun 2008 disempurnakan Nomor 248 Tahun 2010.

Peraturan Pemerintah Nomor 7 Tahun 2008 Tentang Tugas Dekonsentrasi dan Tugas Pembantuan.

Undang-Undang Dasar Republik Indonesia 1945.

Undang-Undang Nomor 17 Tahun 2003.

Undang-Undang Nomor 33 Tahun 2004 Tentang Perimbangan Keuangan Antara Pusat dan Daerah.

Undang-Undang, Nomor 32 Tahun 2004 Tentang Pemerintah Daerah.

* Makalah disampaikan pada acara Seminar Nasional pada tanggal 29 Februari 2012 di Hotel Allson, Jakarta. 